\title{
Dariusz Michalski
}

Akademia Techniczno-Humanistyczna w Bielsku-Białej

e-mail: michalskidariusz@o2.pl

\section{PROPOZYCJA METODY ELIMINUJĄCEJ NIEDOSKONALOŚCI WIELOSTOPNIOWEGO I WIELOBLOKOWEGO RACHUNKU WYNIKÓW W PRZEDSIĘBIORSTWIE Z BRANŻY FMCG}

PROPOSAL OF THE METHOD ELIMINATING THE IMPERFECTIONS OF THE MULTI-STAGE AND MULTI-BLOCK PROFIT STATEMENT IN THE ENTERPRISE FROM THE FMCG SECTOR

DOI: 10.15611/pn.2018.514.25

JEL Classification: M1, M11, M4

\begin{abstract}
Streszczenie: Zadaniem rachunku kosztów jest m.in. właściwy pomiar kosztów działalności przedsiębiorstwa, a także prawidłowe przedstawienie źródeł ich powstania, stąd powstaje potencjał do optymalizacji kosztów dzięki wykreowaniu cybernetycznego systemu sprzężeń zwrotnych, mającego swe źródło bezpośrednio w pomiarze dokonań. Błędne zakwalifikowanie kosztów na etapie pomiaru dokonań segmentów działalności przedsiębiorstwa czy jego ośrodków odpowiedzialności przyczynia się do powstania nieefektywności w rezultacie niewłaściwych oddziaływań motywujących. Dzieje się tak, gdy rachunek marż pokrycia przedstawia nieprawidłowo udział poszczególnych produktów w kreowaniu wartości dodanej. Stąd celem artykułu jest identyfikacja potencjalnych niedoskonałości rachunku marż pokrycia, mogących generować obniżenie efektywności funkcjonowania przedsiębiorstwa, oraz zaproponowanie rozwiązania $\mathrm{w}$ zakresie wyeliminowania potencjalnych nieefektywności w informacji zarządczej. Autor zastosował metody: obserwacji oraz analizy i krytyki opisywanego w literaturze wielostopniowego i wieloblokowego rachunku wyników.
\end{abstract}

Słowa kluczowe: rachunkowość zarządcza, koszty, próg rentowności, zysk ekonomiczny, raportowanie zysku.

Summary: Assuming that one of the tasks of cost accounting is not only to correctly measure the costs of an enterprise, but also to present in the proper way sources of their generation, the potential for cost optimization is created by a cybernetic feedback system, having its source directly in the measurement of results. An incorrect classification of costs at the stage of measuring the results of business segments or its responsibility centers contributes to inefficiencies resulting from inadequate motivation impacts. This is the case when the coverage margin statement provides incorrect information about the share of individual products in the creation of value added in the enterprise.In particular, the lack of proper 
analytics and allocation of fixed costs generated by particular products may cause the falsity of profitability of some products or customers. The author strives to identify the faults of the contribution margin disclosure that contribute to the reduction of the results of the companies and proposes a solution to eliminate mentioned imperfections.

Keywords: management accounting, costs, contribution margin, economic profit, profit reporting.

\section{Wstęp}

System informacji zarządczej powinien dostarczać prawidłowych informacji, wspierających podejmowanie decyzji i zapewniających skuteczność oddziaływań motywacyjnych. Skuteczność ta powinna zapewniać przynajmniej osiągnięcie planu na poziomie wyników ekonomicznych. Stąd istotne jest znalezienie odpowiedzi na pytanie, czy otrzymane informacje, wygenerowane w trakcie pomiaru dokonań, przyczyniają się do realizacji celów przedsiębiorstwa i skutecznie wspierają efektywne wykorzystanie jego zasobów. Zatem informacja zarządcza powinna nie tylko pozwalać na rozliczenie dokonań pracowników, ale także, poprzez kreowanie odpowiednich oddziaływań sterujących, przyczyniać się do optymalizacji kosztów ponoszonych przez przedsiębiorstwo. Kierownictwo przedsiębiorstw z branży FMCG ${ }^{1}$ potrzebuje precyzyjnych informacji zarówno o rentowności klientów, jak i wartości kreowanej przez poszczególnych menedżerów sprzedaży, aby podejmować właściwe decyzje w otoczeniu, które cechuje wysoka konkurencja oraz idąca w ślad za tym przypadkowość. Zmienność ta wymusza także stałe dostosowanie kontroli zarządzania w przedsiębiorstwie do nowych wyzwań. Stąd istotna jest jakość instrumentów pomiaru dokonań, a szczególnie znalezienie odpowiedzi na pytanie o rzeczywiste koszty, które są związane $\mathrm{z}$ osiągnięciem raportowanego wyniku. Zagadnienia te stały się inspiracją dla autora do podjęcia rozważań dotyczących niedoskonałości wieloblokowego i wielosegmentowego rachunku wyników w zarządzaniu wynikami ekonomicznymi w przedsiębiorstwie z branży FMCG oraz generowania sygnałów sterujących decyzjami menedżerów. Celami autora są: identyfikacja potencjalnych niedoskonałości rachunku marż pokrycia, mogących generować obniżenie efektywności funkcjonowania przedsiębiorstwa oraz zaproponowanie rozwiązania w zakresie wyeliminowania potencjalnych nieefektywności w informacji zarządczej. W tym celu autor zastosował zarówno metodę obserwacji, jak i analizy i krytyki, opisywanego w literaturze, wielostopniowego i wieloblokowego rachunku wyników.

${ }^{1}$ Fast Moving Consumer Goods (FMCG) - do branży FMCG zalicza się przedsiębiorstwa oferujące produkty szybko rotujące, innymi słowy szybko zbywalne, zaspokające codzienne potrzeby konsumentów - m.in.: artykuły spożywcze, ale również kosmetyki, środki czystości, środki higieny, alkohol czy papierosy. Branża ta jest charakteryzowana przez wysoką konkurencję nie tylko w zakresie zaspokajania potrzeb konsumentów, ale i szybkości odpowiedzi na zmianę ich gustów i preferencji. Stąd niezwykle istotna jest ciągła identyfikacja produktów, które zapewniają przedsiębiorstwu wymaganą masę marży przy zachowaniu konkurencyjności na rynku. 


\section{Pomiar wyników za pomocą marży pokrycia}

Wielostopniowy i wieloblokowy rachunek wyników pozwala na odwzorowanie zarówno ogólnej struktury marży pokrycia, jak i marży w poszczególnych segmentach działalności operacyjnej przedsiębiorstwa. Tak określone wyniki operacyjne stają się także elementem zarówno wieloblokowej i wielosegmentowej analizy rentowności funkcjonowania przedsiębiorstwa, jak i monitorowania realizacji planu rozpisanie planu biznesu przedsiębiorstwa zgodnie ze schematem realizowanej analizy oraz konsekwentna analiza osiągniętych wyników pozwala na precyzyjne określenie powodów odchyleń od planu. Ponadto różne perspektywy i stopnie analizy pozwalają ocenić kluczowe czynniki, od których zależy wynik funkcjonowania przedsiębiorstwa z branży FMCG. Na ich podstawie należy podejmować skuteczne decyzje poprawiające efektywność funkcjonowania przedsiębiorstwa oraz skutecznie sterujące realizacją jego celów.

Marża pokrycia, która służy do oceny wyników funkcjonowania ośrodków odpowiedzialności w przedsiębiorstwie, stanowi różnicę między przychodami ze sprzedaży osiąganymi przez dany ośrodek a kosztami kontrolowanymi przez ten ośrodek. Stąd należy dokonać dekompozycji kosztów kontrolowanych przez ośrodek odpowiedzialności na koszty zmienne ośrodka i kontrolowane przez niego koszty stałe (zazwyczaj koszty stałe bezpośrednie). Na tej podstawie należy określić dwa poziomy marży pokrycia (oprac. na podst.: [Nowak 2009, s. 205]):

1) zmienna marża pokrycia - stanowi różnicę przychodów ze sprzedaży i kosztów zmiennych ośrodka;

2) kontrolowana marża pokrycia - jest to różnica zmiennej marży pokrycia i kontrolowanych kosztów stałych; kontrolowana marża pokrycia powinna stać się miarą wyników ośrodków odpowiedzialności.

Stąd wieloblokowy i wielostopniowy rachunek marż pokrycia, będąc narzędziem wykorzystywanym do pomiaru dokonań menedżerów ośrodków odpowiedzialności w przedsiębiorstwach z branży FMCG, powinien bazować na kontrolowanej marży pokrycia. Poszczególne stopnie kalkulacji marży pokrycia, będące integralną częścią tego rachunku, stanowią punkt odniesienia do wynagradzania menedżerów za dokonania. W sposób syntetyczny zostają przedstawione poziomy tych marż dla różnych poziomów analitycznych funkcjonowania przedsiębiorstwa. Tak przygotowany raport wyników jest rozwinięciem rachunku kosztów zmiennych zarówno o pozycje wynikowe (stopnie wyniku), jak i przypisanie kontrolowanych kosztów stałych do szeregu bloków (segmenty działalności) ${ }^{2}$ - zakładając, że część kosztów stałych należy traktować jako koszty bezpośrednie odpowiednich

2 Bloki działalności to elementy organizacji, dla których można skalkulować wynik operacyjny, segmenty te powinny zostać określone zgodnie z preferencjami osób kierujących przedsiębiorstwem i z analitycznym podziałem przedsiębiorstwa. Tak wyodrębniona struktura segmentów może się różnić od struktury ośrodków odpowiedzialności. Zob.: [Drury 2002, s. 418; Jarugowa, Nowak, Szychta 1997, s. 26; Nowak 2003, s. 188]. 
grup asortymentowych czy produktów, inne zaś jako koszty pośrednie, które należy przypisać za pomocą kluczy podziałowych. Bloki zostają wyodrębnione w celu grupowania przychodów i kosztów w sposób odzwierciedlający zjawiska zachodzące w przedsiębiorstwie, ich elementy i wzajemne powiązania. Segmenty zaś są wyróżniane zgodnie z potrzebą analizy efektywności różnych rodzajów działalności operacyjnej przedsiębiorstwa oraz długości okresu stabilności kosztów stałych. Kolejne stopnie analizy wyniku ekonomicznego, bazującej na rachunku kosztów zmiennych, umożliwiają uwzględnienie coraz większego wpływu kosztów stałych na wynik ze sprzedaży produktów, co pozwala wyliczyć kolejne stopnie marży pokrycia i finalnie wynik ze sprzedaży produktów zarówno dla poszczególnych produktów, jak i globalnie dla przedsiębiorstwa [Nowak 2012, s. 103].

- Jednostopniowy rachunek kosztów zmiennych może być z powodzeniem stosowany w małych, jednooddziałowych przedsiębiorstwach, wytwarzających jednorodny produkt. W większych przedsiębiorstwach wielooddziałowych, produkujących zróżnicowany asortyment wyrobów, jednostopniowy rachunek kosztów zmiennych nie zapewnia dostatecznej informacji dotyczącej struktury kosztów i marży pokrycia z uwagi na wysoki poziom agregacji informacji.

- Punktem wyjścia do konstrukcji wielostopniowego i wieloblokowego rachunku wyników jest dwustopniowy rachunek kosztów zmiennych:

Przychody ze sprzedaży produktów

- Zmienne koszty wytworzenia sprzedanych produktów

= Marża pokrycia

- Koszty stałe

= Wynik operacyjny

Rachunek kosztów zmiennych w standardowej postaci może być bezpośrednio wykorzystywany głównie w przedsiębiorstwach jednoodziałowych, wytwarzających jednorodny produkt. Prowadzenie krótkookresowego rachunku wyników na bazie rachunków kosztów zmiennych oparte jest na dwóch założeniach. Zakłada się, że:

1) przychód ze sprzedaży produktów jest proporcjonalny do wielkości sprzedaży produktów;

2) koszty własne sprzedanych produktów zależą liniowo od wielkości produkcji.

Koszty własne sprzedanych produktów obejmują przy tym dwie grupy kosztów:

a) koszty zmienne wytworzenia sprzedanych produktów,

b) koszty stałe okresu, na które składają się:

- stałe pośrednie koszty produkcji,

- pośrednie koszty nieprodukcyjne.

Wynik ze sprzedaży ustalony na bazie rachunku kosztów zmiennych jest zatem różnicą między globalną marżą pokrycia a kosztami stałymi okresu. Wynika z tego, 
że krótkookresowy wynik finansowy oparty na rachunku kosztów zmiennych jest ustalany dwuetapowo. W pierwszym etapie ustala się marżę pokrycia jako różnicę przychodów ze sprzedaży produktów i kosztów zmiennych sprzedanych produktów, w drugim zaś ustala się wynik ze sprzedaży produktów jako różnicę marży pokrycia i kosztów stałych okresu.

W przedsiębiorstwach wielooddziałowych i w przypadku produkcji wieloasortymentowej taki rachunek ma natomiast ograniczone możliwości zastosowań ze względu na małą przydatność informacyjną. Chodzi głównie o zbyt wysoki poziom agregacji informacji opisujących strukturę kosztów, wpływających na poszczególne stopnie marży pokrycia oraz ogólności ustalania wyniku finansowego. W takim przypadku koszty stałe nie powinny być rozpatrywane jako jedna wielkość. Należy natomiast przeanalizować strukturę powstawania tych kosztów i rozpatrywać je w pewnych segmentach, które dotyczą różnych zakresów działalności. Jednocześnie globalna marża pokrycia wypracowana w rezultacie sprzedaży wyrobów gotowych powinna być także wyliczana stopniowo przy uwzględnieniu różnych zakresów kosztów stałych. Takie rozliczenie kosztów stałych i marży pokrycia przyczyni się do wzrostu wartości informacyjnej rachunku kosztów zmiennych oraz zwiększenia jego przydatności jako instrumentu kontroli kosztów i osiąganych wyników na różnych poziomach działalności przedsiębiorstwa. To zdecydowało o wyodrębnieniu się różnych odmian rachunków kosztów zmiennych, określanych mianem segmentowego rachunku kosztów zmiennych. Do odmian takich należy zaliczyć przede wszystkim wielostopniowy rachunek kosztów zmiennych oraz wielkoblokowy rachunek kosztów zmiennych.

Podsumowując, należy wskazać następujące różnice pomiędzy wielostopniowym a wieloblokowym rachunkiem kosztów zmiennych:

1) wielostopniowy rachunek kosztów zmiennych - w tym systemie koszty stałe rozdzielane są względem rodzajów działalności (koszty stałe wydziałowe, koszty sprzedaży, koszty ogólnego zarządu);

2) wieloblokowy rachunek kosztów zmiennych - wykorzystywany jest w przedsiębiorstwach wielooddziałowych i w warunkach produkcji wieloasortymentowej; bloki kosztów stałych przyporządkowywane są różnym podmiotom (oddziałom, wydziałom) oraz produktom (grupom asortymentowym, indywidualnym produktom).

W wyniku połączenia wielostopniowego oraz wieloblokowego rachunku kosztów zmiennych otrzymuje się wielosegmentowy rachunek kosztów zmiennych.

\section{Struktura wieloblokowego i wielosegmentowego rachunku wyników}

Pionowy podział rachunku kosztów zmiennych pozwala przypisać koszty stałe do poszczególnych stopni wyników, zaś poziomy podział pozwala wyodrębnić seg- 
menty analizy zgodnie ze zdefiniowanymi wymogami analitycznymi. Podejście to determinuje strukturę zarówno stopni analizy, jak i jej segmentów w rachunku wyników. Najczęściej analizuje się marże pokrycia dla produktów, asortymentów produkcji, kanałów dystrybucji, klientów, segmentów rynku. Zasadą jest stopniowalność analizowanych marż pokrycia. Jak już wspomniano, ich ilość uzależniona jest od oczekiwanej szczegółowości informacji o czynnikach wpływających na kreowanie wyników ekonomicznych w przedsiębiorstwie i bardziej szczegółowo, w poszczególnych blokach i segmentach analizy. Stąd należy stwierdzić, że wieloblokowość rachunku marż pokrycia jest pochodną przyjętych założeń co do struktury obiektów kalkulacyjnych - im bardziej rozbudowany jest układ hierarchiczny tych obiektów, tym większa wieloblokowość [Szydełko 2016]. Generalnie, tak skonstruowany rachunek wyników, bazujący na poszczególnych stopniach kreowania marży pokrycia, wskazuje w sposób syntetyczny kształtowanie się marż pokrycia na poszczególnych poziomach analitycznych funkcjonowania przedsiębiorstwa.

Wielostopniowy rachunek kosztów zmiennych należy opisać zgodnie z poniższym schematem:

1) Przychody ze sprzedaży produktów

- Zmienne koszty wytworzenia sprzedanych produktów

$=$ Marża pokrycia I

Marża pokrycia I oznacza wynik wypracowany na kosztach zmiennych. Wartość sprzedaży zostaje pomniejszona o koszty zmienne wyprodukowania sprzedanych wyrobów gotowych (surowce, opakowania, robocizna, materiały niemagazynowe). W ten sposób określony zostaje wynik z produkcji bez uwzględnienia kosztów stałych.

2) = Marża pokrycia I

- Zmienne koszty transportu

= Marża pokrycia II

Marża pokrycia II uwzględnia koszty transportu.

3) = Marża pokrycia II

- Koszty sprzedaży

= Marża pokrycia III

Koszty sprzedaży powinny zawierać całość kosztów związanych ze strukturą organizacyjną sprzedaży: koszty przedstawicieli handlowych, administracji sprzedaży, kierownictwo sprzedaży, koszty osób z obszaru marketingu realizujących wsparcie marketingowe sprzedaży oraz koszty usług podmiotów zewnętrznych, które wspierają przedsiębiorstwo w działalności handlowej. Marża pokrycia III powinna zawierać dodatkowo wszystkie koszty związane ze wsparciem sprzedaży 
produktów (tzw. trade marketing, rabaty, upusty, materiały wspierające sprzedaż). Ten stopień rachunku kosztów zmiennych powinien być wykorzystywany do analizy efektywności sprzedaży.

4) = Marża pokrycia III

- Koszty wydziałowe

= Marża pokrycia IV

Koszty wydziałowe dotyczą kosztów stałych produkcji (w tym amortyzacji) nieprzypisanych do marży I.

5) = Marża pokrycia IV

- Koszty ogólnego zarządu

= Wynik operacyjny

Marża pokrycia IV pomniejszana jest w kolejnym etapie o koszty jednostek sztabowych, które nie zostały wcześniej przypisane do poszczególnych segmentów analizy kosztów, w tym o koszty marketingu niezwiązane z bezpośrednim wspieraniem sprzedaży u klientów. Każdy segment analizy powinien umożliwiać analizowanie specyficznej wartości marży dla określonej kolejności kosztów obciążających przychody przedsiębiorstwa.

Uzupełnieniem segmentowego rachunku kosztów zmiennych jest wielkoblokowy rachunek kosztów zmiennych, który ma zastosowanie w przedsiębiorstwach wielooddziałowych i przy produkcji wieloasortymentowej. Wielkoblokowy rachunek kosztów zmiennych zakłada rozpatrywanie kosztów stałych w pewnych blokach, przyporządkowanych różnym zakresom podmiotowym i różnym zakresom przedmiotowym, do których powinny zostać przypisane kontrolowane koszty stałe. Takie rozliczenia umożliwiają zastosowanie indywidualnego podejścia do kosztów stałych w przekroju nośników kosztów wynikających z prowadzonej działalności. Koszty stałe nośników kosztów są zazwyczaj ujmowane odrębnie w przekroju dwóch poziomów nośników:

1) indywidualnych asortymentów produktów,

2) grup asortymentowych produktów.

Często grupuje się koszty stałe jedynie dla całego przedsiębiorstwa.

Analityczny podział firmy dokonywany jest z perspektywy wymaganych informacji przez decydentów (kierownictwo) firmy. Podział ten jest możliwy do przeprowadzenia z punktu widzenia różnych kryteriów, mogących stanowić segmenty analizy dla wieloblokowego rachunku wyników:

1) Kryterium przedmiotowe:

- podział na produkty - kryterium podziału jest produkt lub grupa produktów; cel rachunkowości zarządczej to określenie rentowności poszczególnych produk- 
tów, zaś efektem pomiaru dokonań jest wynik będący sumą wyników z poszczególnych produktów;

- podział wg klientów - kryterium podziału to różne typy klientów lub poszczególni klienci, cel rachunkowości zarządczej to określenie rentowności poszczególnych klientów, zaś efektem pomiaru powinien być wynik będący sumą wyników z poszczególnych klientów oraz właściwie ukształtowana polityka firmy uzależniona od poziomów rentowności poszczególnych klientów lub ich grup.

2) Kryterium podmiotowe - dotyczy podziału na podmioty kosztowe lub kosztowo-przychodowe (ośrodki analizy, działalności); kryterium podziału to ośrodki odpowiedzialności - mogą to być zakłady, działy, sekcje. Celem tego segmentu podziału jest ocena wyników poszczególnych ośrodków odpowiedzialnych za ponoszone koszty i osiągnięte rezultaty.

Przedsiębiorstwo posiada w zależności od rodzaju prowadzonej działalności organizację funkcjonalną opartą na czterech podstawowych funkcjach:

a) zaopatrzenie - dział zaopatrzenia, zakupów, logistyki itd.,

b) produkcja - pion, dział produkcji,

c) handel - działy handlowe, zbytu,

d) administracja - dyrekcja naczelna, działy administracyjno-finansowe.

W praktyce ta działalność jest znacznie szersza i w większych przedsiębiorstwach powyższy podział w skali działów jest rozbudowywany do poddziałów, przykładowo:

- obszar administracyjno-finansowy: dział administracyjny, dział księgowości, dział dokumentacji, dział informatyczny,

- obszar kontroli zarządzania: rachunkowość sprzedaży/klientów, rachunkowość zakupów/dostawców, rachunkowość ogólna, rachunkowość zarządcza.

Jednostką podstawową działalności jest stanowisko pracy - odpowiada ono jednej lub kilku operacjom (operator maszyny, handlowiec).

1) Kryterium dystrybucyjne - bazuje zazwyczaj na podziale geograficznym sprzedaży. Celem pomiaru jest określenie rentowności działalności w różnych regionach, województwach czy krajach. Kryterium to może zostać rozszerzone o dodatkowe elementy tego podziału:

- prowadzona działalność (produkcja, usługi, dystrybucja itd.),

- polityka i strategia (koncentracja na jednej dziedzinie działalności, rozszerzenie na inne, przewidywany wzrost działalności),

- organizacja wewnętrzna (organizacja zdecentralizowana, podział na ośrodki działalności).

W praktyce podział analityczny uwzględnia kilka modeli podziału z przedstawionych powyżej. Istotne jest, że każdy z wyróżnionych segmentów (bloków) działalności może zostać potraktowany jako ośrodek odpowiedzialności za wyniki, którego miarą rezultatu będzie zrealizowana marża pokrycia [Nowak 2012, s. 103]. 
Tabela 1. Przykład wieloblokowego i wielostopniowego rachunku kosztów zmiennych

\begin{tabular}{|c|c|c|c|c|c|c|c|c|}
\hline \multirow{7}{*}{ Wyszczególnienie } & \multicolumn{8}{|c|}{ Przedsiębiorstwo } \\
\hline & \multicolumn{8}{|c|}{ Oddziały produkcyjne } \\
\hline & \multicolumn{4}{|c|}{ Oddział nr 1} & \multicolumn{4}{|c|}{ Oddział nr 2} \\
\hline & \multicolumn{8}{|c|}{ Grupy produktów } \\
\hline & \multicolumn{2}{|c|}{$\mathrm{Z1}$} & \multicolumn{2}{|c|}{$\mathrm{Z} 2$} & \multicolumn{2}{|c|}{$\mathrm{Z3}$} & \multicolumn{2}{|c|}{$\mathrm{Z} 4$} \\
\hline & \multicolumn{8}{|c|}{ Produkty } \\
\hline & A1 & A2 & A3 & A4 & A5 & A6 & A7 & A8 \\
\hline $\begin{array}{l}\text { Przychód ze } \\
\text { sprzedaży }\end{array}$ & 158 & 92 & 324 & 250 & 450 & 321 & 328 & 410 \\
\hline Koszty zmienne & -40 & -41 & -81 & -65 & -200 & -83 & -95 & -130 \\
\hline Marża pokrycia I & 118 & 51 & 243 & 185 & 250 & 238 & 233 & 280 \\
\hline Koszty logistyki & -19 & -23 & -42 & -33 & -90 & -61 & -56 & -70 \\
\hline Marża pokrycia II & 99 & 28 & 201 & 152 & 160 & 177 & 177 & 210 \\
\hline Koszty sprzedaży & -19 & -13 & -42 & -33 & -74 & -61 & -56 & -170 \\
\hline Marża pokrycia III & 80 & 15 & 159 & 119 & 86 & 116 & 121 & 40 \\
\hline $\begin{array}{l}\text { Marża pokrycia III } \\
\text { grup produktów }\end{array}$ & \multicolumn{2}{|c|}{95} & \multicolumn{2}{|c|}{278} & \multicolumn{2}{|c|}{202} & \multicolumn{2}{|c|}{161} \\
\hline $\begin{array}{l}\text { Koszty wydziałowe } \\
\text { bezpośrednie }\end{array}$ & \multicolumn{2}{|c|}{-15} & \multicolumn{2}{|c|}{-34} & \multicolumn{2}{|c|}{-40} & \multicolumn{2}{|c|}{-42} \\
\hline $\begin{array}{l}\text { Marża pokrycia III } \\
\text { oddziału }\end{array}$ & \multicolumn{4}{|c|}{324} & \multicolumn{4}{|c|}{281} \\
\hline $\begin{array}{l}\text { Koszty wydziałowe } \\
\text { pośrednie }\end{array}$ & \multicolumn{4}{|c|}{-247} & \multicolumn{4}{|c|}{-177} \\
\hline $\begin{array}{l}\text { Marża pokrycia IV } \\
\text { (oddzialów) }\end{array}$ & \multicolumn{4}{|c|}{77} & \multicolumn{4}{|c|}{104} \\
\hline $\begin{array}{l}\text { Suma marż } \\
\text { pokrycia IV } \\
\text { oddzialów } \\
\end{array}$ & \multicolumn{8}{|c|}{181} \\
\hline $\begin{array}{l}\text { Koszty ogólnego } \\
\text { zarządu }\end{array}$ & \multicolumn{8}{|c|}{-98} \\
\hline $\begin{array}{l}\text { Wynik ze } \\
\text { sprzedaży }\end{array}$ & \multicolumn{8}{|c|}{83} \\
\hline
\end{tabular}

Źródło: opracowanie własne.

\section{Przykłady niedoskonałości wieloblokowego i wielosegmentowego rachunku marż pokrycia, wpływających na pogorszenie efektywności funkcjonowania przedsiębiorstwa}

Z omawianego przykładu w sposób prosty i czytelny uzyskuje się informacje o osiągniętych wynikach na poszczególnym asortymencie, jak również na każdym poziomie kosztów. Jednakże wyliczenie marży zysku (marża IV) dla całego przedsiębiorstwa nie daje możliwości zarządzania, stąd istotne jest poprawienie alokacji 
kosztów na produkty i klientów. Należy zatem wskazać następujące możliwości poprawy jakości informacji zarządczej przedstawianej w rezultacie kalkulacji wieloblokowego i wielosegmentowego rachunku wyników.

\section{Amortyzacja}

Rozliczenie amortyzacji na produkty powinno zostać zrealizowane za pomocą klucza podziałowego bazującego na czasie wykorzystania maszyn do produkcji określonego produktu (indeksu). W tym celu należy wdrożyć pomiar czasu pracy maszyn na rzecz każdego zlecenia produkcyjnego. Stanie się on podstawą przypisania kosztów amortyzacji w marży I do poszczególnych produktów, co pozwoli także uniknąć nieuzasadnionego zafałszowania rentowności poszczególnych produktów (wręcz ich wzajemnego subsydiowania). Prawidłowe obciążenie produktów kosztem amortyzacji powinno prowadzić do zwiększenia obłożenia maszyn już zamortyzowanych, ale mniej wydajnych.

\section{Przezbrojenia}

Przezbrojenia mogą generować wysokie koszty związane nie tylko z operacjami wynikającymi z przygotowania maszyn do produkcji innych produktów niż wcześniej, ale także z kosztem utraconych możliwości niewykorzystanego potencjału. Ten drugi aspekt nie jest zazwyczaj brany pod uwagę, a może mieć istotne znaczenie dla rentowności zlecenia, jeżeli dotyczy ono relatywnie niewielkiego wolumenu produkcji, a czas przezbrojenia jest znaczący dla powstania kosztów alternatywnych wielkości alternatywnej produkcji (np. zastosowanie agresywnych komponentów, które wymagają długotrwałego mycia urządzeń3). Jeżeli ten aspekt związany z kosztami produkcji zostanie pominięty, to może się okazać, że rentowność, za którą jest rozliczany menedżer sprzedaży, może nie gwarantować oddziaływań motywacyjnych, które będą poprawiać wyniki ekonomiczne przedsiębiorstwa. Wręcz odwrotnie, menedżer, sprzedając coraz więcej produktów wytwarzanych w krótkich seriach, może zwiększać wykonanie swych celów premiowych, jednocześnie pogarszając wyniki ekonomiczne przedsiębiorstwa. Stąd koszty związane z przezbrojeniami powinny zostać rozliczone jako koszty stałe bezpośrednie produkcji i obciążać marżę, za którą jest rozliczany menedżer sprzedaży.

\section{Koszty logistyki - kompletacja}

Na rentowność produktów oraz klientów wpływają koszty logistyczne. Dotyczy to m.in. kosztów kompletacji, które dla wielkiej ilości indeksów w zleceniu mogą być znaczące dla rentowności sprzedaży. Stąd należy wskazać, że dla ochrony wyników ekonomicznych przedsiębiorstwa i zapewnienia spójności oddziaływań motywacyjnych należy rozliczyć te koszty w marży, która jest podstawą rozliczenia celów premiowych sprzedawców, traktując koszty kompletacji jako koszty stałe bezpośrednie. Jeżeli koszt ten zostanie rozliczony niewłaściwym kluczem podziałowym, to może się okazać, podobnie jak dla kosztu przezbrojeń, że sprzedawcy będą maksy-

\footnotetext{
${ }^{3}$ Czas mycia niejednokrotnie jest dłuższy niż czas produkcji określonego zlecenia.
} 
malizować swe cele premiowe, zwiększając sprzedaż, która jednak poprzez generowanie wysokich kosztów logistyki magazynowej będzie redukować wyniki ekonomiczne przedsiębiorstwa.

\section{Zakup efektywniejszych maszyn}

Zakup nowych maszyn sprawia, że obniżone zostają koszty wytworzenia produktów. W takiej sytuacji menedżerowie sprzedaży będą dążyć do przeniesienia produkcji z maszyn mniej wydajnych i o wyższych kosztach na nowe maszyny, gwarantujące im poprawę rentowności sprzedaży. Jednakże koszty maszyn, na których zaprzestano produkcji, pozostają dalej w przedsiębiorstwie - w myśl założenia, że najdroższa jest ta maszyna, która nie produkuje. Stąd należy znaleźć rozwiązanie, które w informacji zarządczej uwzględni koszty maszyn, które nie pracują, i zaalokuje je do rentowności, za którą są rozliczani menedżerowie sprzedaży, lub przeniesie je do systemu motywacyjnego - np. wymóg osiągnięcia wymaganej wartości wskaźnika OEE. Generalnie należy wskazać, że rozwiązania przyjęte w wieloblokowym i wielosegmentowym rachunku wyników mogą prowadzić do wygenerowania niewłaściwych oddziaływań sterujących. Z drugiej strony maszyny, które nie zostają obłożone w wymaganej wysokości, powinny zostać sprzedane lub zezłomowane.

\section{Wieloasortymentowość}

Menedżer sprzedaży, jeżeli nie zostanie w marży, za którą jest rozliczany, obciążony wszystkimi kosztami, które generują jego decyzje, będzie dążyć do sprzedaży wielu produktów, gdyż wynik raportowany będzie wyższy niż rzeczywiście osiągany przez przedsiębiorstwo. Stąd maksymalizacja wyniku menedżera, za który jest on wynagradzany w systemie motywacyjnym, nie jest skorelowana z poprawą wyników ekonomicznych przedsiębiorstwa.

\section{Możliwości modyfikacji wieloblokowego i wielosegmentowego rachunku wyników w celu poprawy informacji zarządczej}

Zatem wieloblokowość rachunku wyników powinna być rezultatem uwzględnienia różnego stopnia generowania kosztów stałych w poszczególnych przekrojach analitycznych stosowanych w przedsiębiorstwie. Konieczne jest zastosowanie następujących sposobów analizowania i w kolejnym kroku alokowania kosztów stałych (oprac. na podst.: [Błoch 1998, s. 114]):

- perspektywa produktu - koszty stałe (najczęściej bezpośrednie), które można bezpośrednio przypisać określonym wyrobom gotowym (koszty stałe bezpośrednie);

- perspektywa grupy produktów - koszty stałe, które nie mogą zostać przypisane do pojedynczego produktu, ale mogą zostać zaalokowane do grupy produktów (koszty stałe pośrednie); 
- perspektywa kilku grup produktów - koszty odnoszone do kilku grup produktów (koszty stałe pośrednie);

- koszty stałe ogólnego zarządu przypisane do obszarów funkcjonalnych kosztów;

- koszty stałe ogólnego zarządu.

Każdy produkt ma inną charakterystykę pod względem fazy życia, potencjału rynkowego czy sezonowości sprzedaży, stąd wszystkie elementy kalkulacji wyników ekonomicznych powinny być kalkulowane indywidualnie, co pozwala uniknąć obciążenia produktów czy klientów rentownych kosztami generowanymi przez mniej rentowne produkty (więcej zob. [Bender 2008]. Stąd istotne jest odpowiednie podzielenie kosztów nie tylko pomiędzy grupy asortymentowe produktów, ale także poszczególne produkty, tak aby można było ocenić rzeczywisty wynik generowany przez każdy z nich. Należy dążyć do rzetelnego odwzorowania w rachunku marż pokrycia rzeczywistego obrazu kosztów rozwiązań techniczno-organizacyjnych oraz realizowanych przy ich udziale zadań i procesów. W tym celu należy przyjąć, że koszty sprzedaży oraz koszty ogólnego zarządu są kosztami umownie stałymi - część tych kosztów jest także kosztami zmiennymi [Nowak 2012, s. 104]. Koszty stałe bezpośrednie, które można przypisać poszczególnym produktom, powinny być grupowane indywidualnie, zaś koszty stałe pośrednie, które są przypisane grupom asortymentowym, powinny zostać za pomocą rachunku kosztów (np. rachunku kosztów działań) przypisane produktom. Zatem rachunek marż pokrycia powinien zostać skorygowany w następujący sposób:

- Marża pokrycia I powinna uwzględniać koszty stałe bezpośrednie powstałe w wyniku realizacji zleceń produkcyjnych, szczególnie koszty przezbrojenia maszyn, które mogą zostać pominięte $\mathrm{w}$ analizie rentowności sprzedaży, jeżeli będą uwzględnione w kosztach wydziałowych. Podobnie należy obciążyć marżę I kosztami stałymi produkcji, które można precyzyjnie przypisać do produktów (produkt jest czynnikiem generującym powstanie kosztu stałego). Jeżeli powyższe zmiany nie zostaną wprowadzone, to system raportowania będzie promować krótkie serie i zlecenia, bo koszty stałe bezpośrednie, generowane przez decyzje menedżerów, nie są ujmowane bezpośrednio w marży I zgodnie z rzeczywistym kosztem, który wywołują, ale zgodnie z teoretycznym kluczem podziałowym w marży IV (rozliczenie rentowności sprzedaży jest na podstawie marży III, a część kosztów przeniesiona została do marży IV).

- Koszty związane z przygotowaniem produktów do wysyłki - koszty stałe bezpośrednie, powstałe np. w wyniku kompletacji wysyłki wielu indeksów w ramach jednego zlecenia, powinny być przypisane do zlecenia je generującego - jeżeli będą zaalokowane do kosztów wydziałowych, to zostanie zafałszowana rentowność sprzedaży. Zatem koszty kompletacji wysyłek należy traktować jako kontrolowane koszty wydziałowe, które należy za pomocą klucza podziałowego (np. za pomocą rachunku kosztów działań sterowanych czasem, TdABC) przypisać do generujących te koszty produktów, co sprawi, że zjawisko ukrytego subsydiowania części wysyłek (niewłaściwa alokacja kosztów ponoszonych na 
magazynach i w strefach kompletacji wysyłek) zostanie wyeliminowane. Koszty logistyki magazynowej i transportu powinny obciążyć marżę II. W przeciwnym razie system raportowania będzie promować zlecenia wieloasortymentowe i krótkie serie, nawet jeżeli wydłuża to koszt kompletacji i pracy magazynierów (czas, liczba operacji) oraz produkcji, a koszty te zostają dopiero rozliczone w marży IV, co jest błędne, jeżeli rozliczenie rentowności sprzedaży bazuje na wartości marży III. Dodatkowo klucze podziałowe wykorzystywane w marży IV zazwyczaj nie oddają prawidłowo rzeczywistości (następuje subsydiowanie mniej rentownych produktów).

- Do kosztów zmiennych sprzedaży należy przypisać wszystkie koszty związane z marketingowym wsparciem sprzedaży czy współpracy z klientami i obciążyć nimi marżę III. Podobnie koszty sprzedaży związane z pracą przedstawicieli handlowych i obsługą klientów powinny zostać przypisane do kosztów obciążających marżę III. Koszty przedstawicieli handlowych powinny być alokowane do klientów czy produktów za pomocą klucza bazującego na wielkości przychodów, czy technicznego kosztu wytworzenia sprzedanych produktów, co może nie odpowiadać rzeczywistemu obrazowi ponoszonych kosztów w procesie sprzedaży i obsługi klientów. Zatem należy obciążyć kosztami stałymi, które można precyzyjnie przypisać do produktów i klientów, marżę III. Dla rozliczenia kosztów obsługi sprzedaży powinny zostać wdrożone elementy analizy TdABC. Należy połączyć dane z systemów rejestrujących sprzedaż w sklepach oraz czas poświęcony przez przedstawiciela handlowego w sklepie i na tej podstawie określić czas poświęcony na obsługę sprzedaży w poszczególnych punktach handlowych i czas ten przypisać do klientów (zazwyczaj są to dystrybutorzy, a czas został poświęcony na obsługę ich sprzedaży), ale tylko dla sprzedaży obsługiwanej przez przedstawicieli handlowych przedsiębiorstwa. Koszty przedstawicieli handlowych należy podzielić przez globalny czas zarejestrowany w systemie informatycznym, czyli zostaje określony koszt minuty. Kosztem czasu poświęconego na obsługę sprzedaży należy obciążyć odpowiednio każdego dystrybutora/klienta.

Zastosowanie powyższych modyfikacji sprawia, że pozycje kosztowe są analizowane wg ich rzeczywistego wpływu na wyniki sprzedaży oraz jej rentowność, stosując zasadę, że każdy koszt ma swojego właściciela i przekłada się na rentowność funkcjonowania przedsiębiorstwa ${ }^{4}$.

Zasadą powinno być, że do kosztów wydziałowych i ogólnego zarządu alokowane są tylko te koszty, których nie można przypisać do zleceń czy produktów, zaś wszystkie koszty bezpośrednie powinny zostać przypisane do stopnia rachunku kosztów zmiennych, który jest wykorzystywany do analizy rentowności sprzedaży produktów czy zyskowności klientów (w przykładzie analizowanym w artykule marża III). Należy zatem przealokować koszty z marży IV do marży I i marży II.

4 Istotne jest wyeliminowanie alokacji kosztów wg struktury sprzedaży, co sprawia, że zostaje zafałszowany obraz rzeczywistej rentowności działalności operacyjnej przedsiębiorstwa. 
W marży IV powstaje pewnego rodzaju zbiór kosztów stałych, gdzie są ukrywane także koszty nieefektywności, zaś wykorzystanie nieefektywnych kluczy podziałowych prowadzi do wzajemnego subsydiowania produktów - duże serie subsydiują krótkie serie i zlecenia oraz wysyłki wieloasortymentowe.

Tabela 2. Przykład modyfikacji wieloblokowego i wielostopniowego rachunku kosztów zmiennych

\begin{tabular}{|c|c|c|c|c|c|c|c|c|}
\hline \multirow{7}{*}{ Wyszczególnienie } & \multicolumn{8}{|c|}{ Przedsiębiorstwo } \\
\hline & \multicolumn{8}{|c|}{ Oddziały produkcyjne } \\
\hline & \multicolumn{4}{|c|}{ Oddział nr 1} & \multicolumn{4}{|c|}{ Oddział nr 2} \\
\hline & \multicolumn{8}{|c|}{ Grupy produktów } \\
\hline & \multicolumn{2}{|c|}{$\mathrm{Z1}$} & \multicolumn{2}{|c|}{$\mathrm{Z} 2$} & \multicolumn{2}{|c|}{$\mathrm{Z3}$} & \multicolumn{2}{|c|}{$\mathrm{Z4}$} \\
\hline & \multicolumn{8}{|c|}{ Produkty } \\
\hline & A1 & A2 & A3 & A4 & A5 & A6 & A7 & A8 \\
\hline $\begin{array}{l}\text { Przychód ze } \\
\text { sprzedaży }\end{array}$ & 158 & 92 & 324 & 250 & 450 & 321 & 328 & 410 \\
\hline Koszty zmienne & -55 & -42 & -105 & -89 & -200 & -109 & -112 & -136 \\
\hline Marża pokrycia I & 103 & 50 & 219 & 161 & 250 & 212 & 216 & 274 \\
\hline Koszty logistyki & -34 & -27 & -72 & -53 & -111 & -84 & -96 & -82 \\
\hline Marża pokrycia II & 69 & 23 & 147 & 108 & 139 & 128 & 120 & 192 \\
\hline Koszty sprzedaży & -19 & -13 & -42 & -33 & -74 & -61 & -56 & -170 \\
\hline Marża pokrycia III & 50 & 10 & 105 & 75 & 65 & 67 & 64 & 22 \\
\hline $\begin{array}{l}\text { Koszty wydziałowe } \\
\text { pośrednie }\end{array}$ & -30 & -5 & -65 & -63 & -20 & -44 & -40 & -10 \\
\hline Marża pokrycia IV & 20 & 5 & 40 & 12 & 45 & 23 & 24 & 12 \\
\hline $\begin{array}{l}\text { Koszty ogólnego } \\
\text { zarządu }\end{array}$ & -14 & -3 & -16 & -9 & -25 & -14 & -10 & -7 \\
\hline $\begin{array}{l}\text { Wynik ze } \\
\text { sprzedaży }\end{array}$ & 6 & 2 & 24 & 3 & 20 & 9 & 14 & 5 \\
\hline $\begin{array}{l}\text { Wynik ze } \\
\text { sprzedaży razem }\end{array}$ & & & & $\gamma$ & & & & \\
\hline
\end{tabular}

Źródło: opracowanie własne.

Marża pokrycia III powinna prezentować rzeczywisty wynik, który został zdeterminowany decyzjami menedżerów sprzedaży. Stanowi ona także poziom odniesienia dla rozliczania ich wyników ze sprzedaży. Kolejne poziomy marż pokrycia powinny pozwolić kierownictwu przedsiębiorstwa dokonać analizy rzeczywistego wpływu poszczególnych produktów na wysokość kontrolowanych kosztów stałych przez nie generowanych i w kolejnym kroku, za pomocą narzędzi controllingu produkcji, wskazywać inicjatywy optymalizujące ich poziom (np. wykorzystując Kaizen czy mapowanie strumienia wartości). Przedstawione podejście dotyczy modyfikacji alokacji szczególnie kosztów stałych bezpośrednich oraz w kolejnym kroku kosztów stałych pośrednich (ich analiza może być przeprowadzona za pomocą ele- 
mentów rachunku kosztów działań). W ten sposób uzyskuje się poprawę zarządzania większym zakresem kosztów ponoszonych przez przedsiębiorstwo oraz zwiększa się skuteczność oddziaływań motywujących. Istotne jest w analizie zidentyfikowanie kosztów, które są przypisane do przedsiębiorstwa, ale nie są wykorzystywane do kreowania wartości dodanej, lecz jedynie dotyczą zasobów niewykorzystanych.

Zmiany otoczenia biznesowego przedsiębiorstw wymagają także rozważenia zmian w strukturze wieloblokowego i wielosegmentowego rachunku wyników. Istotne jest także doprowadzenie do wyeliminowania opisanych w artykule niedoskonałości. Zmiany rachunku kosztów zmiennych powinny być wprowadzone w następujący sposób:

2) przez 2 kolejne lata prowadzony jest równolegle rachunek zarówno zgodnie z dotychczasową strukturą, jak i po zmianach - dla zapewnienia porównywalności analizy efektywności menedżerów;

3) w kolejnym roku, jeżeli kierownictwo przedsiębiorstwa uzna, że jest gotowe do zmiany, rachunek wyników może być prowadzony tylko zgodnie z nową strukturą.

\section{Uwagi końcowe}

Wykorzystanie wieloblokowego i wielosegmentowego rachunku kosztów zmiennych pozwala zapewnić skuteczną informację zarządczą, zgodną z analitycznym podziałem obowiązującym w przedsiębiorstwie. Konieczne jest jednak zapewnienie, że tak przygotowane informacje są prawidłowe i odpowiadają rzeczywistości kreowania wartości dodanej w przedsiębiorstwie, a nie tylko formalnie prawdziwe, zgodne z algorytmem kalkulacji marż pokrycia, który jednak w rzeczywistości może kreować oddziaływania motywacyjne pogarszające produktywność funkcjonowania przedsiębiorstwa. Zatem cele, które powinny być realizowane w rezultacie zastosowania wielosegmentowego i wieloblokowego rachunku wyników, nie zostaną osiągnięte, jeżeli wspomniane w artykule jego nieefektywności nie zostaną wyeliminowane dzięki zmianie alokacji poszczególnych kosztów oraz przypisaniu wszystkich segmentów wyników (marż pokrycia) do wyspecyfikowanych elementów analitycznego podziału przedsiębiorstwa. Istotne jest rozliczenie zarówno kosztów zmiennych, jak i stałych na produkty i klientów oraz na tej podstawie ustalenie rzeczywistego wyniku na sprzedaży dla wybranego segmentu. Dopiero w takiej sytuacji informacja zarządcza może wspierać proces podejmowania właściwych decyzji, mających na celu poprawę wyników ekonomicznych zarówno w całym przedsiębiorstwie, jak i jego ośrodkach odpowiedzialności.

Struktura rachunku powinna zatem zostać przystosowana do potrzeb skutecznego sterowania podejmowaniem decyzji przez menedżerów ośrodków odpowiedzialności i skorelowania ich z realizacją celów przedsiębiorstwa dzięki prawidłowym oddziaływaniom motywacyjnym. Wspomniane w artykule potencjalne ryzyko dla decyzji podejmowanych $\mathrm{z}$ interesem decydenta, a nie przedsiębiorstwa wymaga zatem zmiany sposobu alokacji kosztów stałych w analizowanym rachunku marż 
pokrycia. W ten sposób zmodyfikowany rachunek marż pokrycia wspiera zdefiniowanie sformalizowanego podejścia, opartego na cybernetycznym systemie wyprzedzających sprzężeń zwrotnych, powiązanych z oceną efektywności decyzji menedżerów. Podejście to wspiera zrównoważone zarządzanie generowaniem wyników ekonomicznych przedsiębiorstw elektroenergetycznych, jeżeli staje się integralnym elementem systemu zarządzania.

\section{Literatura}

Bender P., 2008, Czym sa marże zysku - jak je wyliczać i analizować?, Monitor Rachunkowości i Finansów, nr 12.

Błoch H., 1998, Jak zapanować nad kosztami?, Oficyna Controllingu Profit, Katowice.

Drury C., 2002, Rachunek kosztów, Wydawnictwo Naukowe PWN, Warszawa.

Jarugowa A., Nowak W.A., Szychta A., 1997, Zarzadzanie kosztami w praktyce światowej, ODDK, Gdańsk.

Nowak E., 2003, Zaawansowana rachunkowość zarzadcza, PWE, Warszawa

Nowak E., 2009, Zaawansowana rachunkowość zarządcza, wyd. II zm., PWE, Warszawa.

Nowak E., 2012, Rachunkowość zarządcza w przedsiębiorstwie, CeDeWu.pl Wydawnictwo Fachowe, Warszawa.

Szydełko Ł., 2015, Segmentowy rachunek kosztów $i$ wyników w rachunkowości zarządczej zorientowanej na procesy, Prace Naukowe Uniwersytetu Ekonomicznego we Wrocławiu, nr 398. 